An interesting 1961 Manitoba breeding record of the Indigo Bunting was sent to the Prairie Nest Records Scheme by Gordon Smith of Winnipeg who noted a nest, July 7, 1961, near Grand Beach.

In addition to the Saskatchewan records we have a record of a WANDERING TATLER (Heteroscelus incanum) seen at Jasper, Alberta, by E. Otto Höhn of the University of Alberta. Professor Höhn recorded his observation in this way: "The bird was seen on the rocky shore of Patricia Lake near the town of Jasper in Jasper National Park on July 2, 1961, at a distance of about 10 yards. It was observed through $10 \times 50$ binoculars. I noted the following points about it at the time: size about that of a Greater Yellowlegs, but more compact in build with relatively thicker and shorter legs; bill black or dark grey, legs yellow. The bird often teetered in the manner of a Spotted Sandpiper. In flight the entire upper surface was an even grey, i e., there were no wing bars and no rump markings. The underparts were irregularly marked with dark grey and white, but did not show the regular barring. I've seen adults of this species on the B.C. coast. The call note was 'tee tee tee tee tee'." Professor Höhn refers to this as the third record of the species for Alberta. The only record given for Alberta in the Birds of Alberta by W. Ray Salt and A. L. Wilk (1958) is a specimen collected May 30,1938 , on the east shore of Swan Lake near the Alberta-B.C. boundary west of Grande Prairie. The bird is not on the Saskatchewan checklist.

\section{TOWNSEND'S SOLITAIRE AT FORT QU'APPELLE}

\section{by E. Manley Callin, Fort San}

This item is written partly to report an extremely rare visitor to this area and partly to describe another personal experience in regard to the value of that "second look". Criticism is frequently levelled, and rightly so, at hasty identifications or "snap judgments" because they may result in a common bird being misidentified and reported as a rare species. However, it is well for us to remember that the danger of the "snap judgment" also works in reverse as it may result in a rare species being passed by in haste.

At 1.30 p.m., on Nov. 10, 1961, I stepped outside our house to return to the office and a casual glance revealed a dark robin-sized bird with fairly long tail reaching for berries in a near-by Mountain Ash. Further details were not clear as I was facing a bright sun and in my hurry I was tempted to accept it as a Pine Grosbeak as that species had been seen many times daily in the area. Fortunately the bird turned at this moment and a light-colored patch was seen on the wing instead of the wing bars of the Grosbeak. I immediately approached the bird from another direction and thus identified my first Townsend's Solitaire in almost 36 years of observation. Though it twice flew a short distance, I eventually watched it with binoculars from a distance of about 25 feet as it fed leisurely upon hawthorn berries or merely perched in its noted attitude of quiet solemnity.

As most of the readers know, the normal home of the Solitaire is in the mountains and foothills but it is noted as an erratic wanderer in spring and fall. Though an occasional bird has been seen at Regina almost every year since 1954, it is considered rare at Regina and is much rarer to the north and east. As a matter of fact I have records of about 20 observers for the eastern half of the Qu'Appelle Valley area, some of the records dating back slightly over 100 years, and not one of the observers has listed the Solitaire.

Editor's Note: The Townsend's Solitaire reported at Regina on the Christmas Count, December 24, 1961, was still in the same location in a small park in the north of the city at the time of The Blue Jay going to press (noted January 20). Active and healthy in appearance, the bird seemed prepared to spend the winter in Regina, as one did in 1960-61. (cf. Margaret Belcher's Birds of Regina. 1961. Spec. Publ. No. 3, S.N.H.S.).

\section{BANDED PURPLE FINCH RECOVERED AT YORKTON}

by Larry A. Morgotch, Yorkton

When Carol Beaumont and Charyl Wiley of Yorkton reported finding a banded Purple Finch along a city (Continued on page 39) 
this material. Mr. Fraser comments further that Bearberry, Arctostaphylos uva-ursa (L.) Spreng, was also used as kinnikinick.

\section{BUFFALO SKULLS}

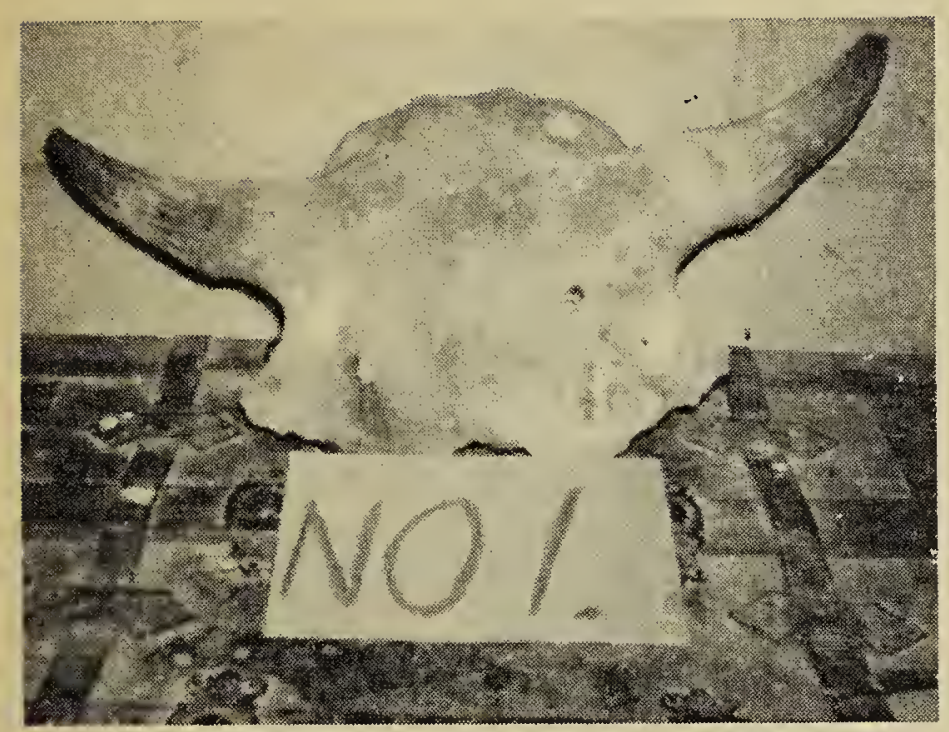

Two photos of buffalo skulls (see fig.) were sent to us in a letter from Ernest J. White, Dunrea, Manitoba. The first skull measured $21 \frac{1}{2}$ inches from one horn point to the other, the second was 24 inches. Mr. White tells that they were found in a deep ravine in what was once a buffalo wallow.

\section{WHY DON'T WE HEAR FROM THE ROCK HOUNDS?}

Miss Dora Doolittle of Oungre, Sask., is a pensioner who has rocks for one of her hobbies, and has made many new friends in this way. She has now a gocid-sized collection which has been of interest to many others beside herself. She wishes the Blue Jay had contributions from the "Rock Hounds".

\section{EFFECTS OF INSECTICIDES}

E. E. Symons of Rocanville, one of the Blue Jay's most faithful contributors, reports on some interesting observations made by his neighbours, Mr. and Mrs Cliff Nixon. The Nixons have been concerned about the effects of insecticides. A couple of years ago, when cutworms were bad and they treated their potatoes with aldrin, they noticed two days later that in two nests of young Robins which they had been watching, every young bird was dead, presumably from eating poisoned worms.

\section{RESOURCES FOR TOMORROW}

Copies of the two-volume set of background papers are presently in public, university and other libraries in the province. A third volume, to include the actual transactions and papers delivered, is now being prepared by Mr. Jack Kinzel of the Department of Industry and Information.-Douglas E. Wade, Regina.

\section{OBSERVATIONS OF A HUNTER WASP}

One hot July afternoon (1961) I saw what I thought at first to be a large green insect walking in the weeds along the driveway. Closer inspection showed it to be a hunter wasp dragging a green caterpillar twice its size. I followed its progress for 25-30 feet, amazed at the way in which it hauled its prey over and around obstacles. The caterpillar was completely immobilized. The hunter wasp paralyzes its victim with its sting in order to supply living food, preserved without decay, for the larva which hatches from the egg laid in a nest prepared ahead of time. The wasp was a black ant-like insect, about the size of the better known yellow jacket wasp, with longer legs and a more slender body. After a time the wasp dropped its prey on a small sandy clearing and opened up a small hole. It then dragged the caterpillar down into what must have been a tunnel at least longer than the caterpillar and wasp together. The wasp went in and out several times. Finally, it painstakingly pushed one large pebble into the opening of the tunnel and arranged sand over it to hide it.-Jack Ferguson, Radville.

\section{(Continued from page 9)}

street, we sent the band to the U.S. Fish and Wildlife Service for information about the bird. It proved to be a female Purple Finch banded May 31, 1960, by Dr. C. Stuart Houston.

The year before one of Dr. Houston's banded Purple Finches was picked up in the same way in Yorkton. Peter Scott found a dead Purple Finch on April 30, 1960, that proved to have been banded on May 17, 1959, in Yorkton (cf. Blue Jay, $19: 21)$. 